\title{
Accounting
}

\section{The role of intellectual capital as a mediation of relationship between audit committee and real earnings management}

\author{
Sri Layla Wahyu Istantia ${ }^{\mathrm{a}} \mathrm{b}^{*}$, Anis Chariri ${ }^{\mathrm{a}}$ and Agung Juliarto ${ }^{\mathrm{a}}$
}

${ }^{a}$ Universitas Diponegoro Semarang, Indonesia

${ }^{b}$ STIE YPPI Rembang, Indonesia

\section{H R O N I C L E}

\section{Article history:}

Received: January 1, 2021

Received in revised format:

April 32021

Accepted: April 4, 2021

Available online:

April 6, 2021

\section{Keywords:}

Audit committee expertise

Number of audit committee meetings

Human capital

Real earnings management

\section{A B S T RA C T}

This study aims to examine the role of human capital, which is part of intellectual capital, as a mediator in the relationship between audit committee expertise and the number of audit committee meetings with real earnings management. This research is a quantitative study. The data source used is data from manufacturing companies in Indonesia. The sample selection technique used purposive sampling. The analysis technique uses path analysis. The results showed that the expertise of the audit committee had a significant effect on human capital, while the number of audit meetings had no effect on human capital. The results of this study also state that audit committee expertise, number of audit committee meetings and human capital performance have no effect on real earnings management actions. Furthermore, there is empirical evidence that shows that human capital has a mediating effect on the relationship between audit committee expertise and the number of audit committee meetings with real earnings management. The role of human capital in the relationship between the expertise of the audit committee and the number of audit committee meetings becomes originality, so it is the main contribution of research. The limitation of this research is that it only uses human capital as a mediating variable.

\section{Introduction}

The main objective of this study is to examine the effect of human capital mediation on the relationship between audit committee expertise and the number of audit meetings on real earnings management. Over the last few years the focus of attention on earnings measurement practices has increased. Profit is one of the important elements used as an indicator of company performance appraisal. Shareholders see the performance of the financial statements from the achievement of company profits from year to year. Cohen \& Zarowin (2010), Roychowdhury (2006) and Zang (2012)state that after the enactment of the Sarbanes Oxley Act (SOX) in America in 2002 there was a tendency for accrual earnings management to shift towards real activities, better known as Real Earnings Management. Roychowdhury (2006) states that Real Earnings Management is a motivation from management to provide a wrong understanding of stakeholders by deviating from the company's normal operating activities. The factors that motivate managers to take REM actions include the opportunistic behavior of management to maximize its utility related to compensation and the intensity received. Gunny (2010)states that earnings management practices, both accrual and real, are thought to affect the quality, reliability and value relevance of financial statements. The opportunistic actions of management in doing practice are the impact of the agency relationship conflict. Agency theory is a

* Corresponding author.

E-mail address: srilayla.undip@gmail.com (S. L. W. Istanti) 
basic concept in corporate governance which is expected to function to reduce the manipulation of earnings by managers so that the reported performance reflects the actual economic condition of the company (Devi \& Iskak, 2018).

In this study, the variables that affect real earnings management are the expertise of the audit committee and the number of audit meetings. Various studies have been conducted to examine the relationship between audit committee expertise and number of audit committee meetings on real earnings management. The existence of empirical evidence explains the mixed results of research between audit committee expertise and the number of audit committee meetings with real earnings management. Susanto \& Pradipta, (2016) research states that the number of audit committee meetings has a significant positive effect on REM, as well as research (Thi, Khanh, \& Khuong, 2018) states that audit quality consisting of audit committee expertise and number of audit committee meetings has a positive effect on REM. However, a different result is shown by Devi \& Iskak's (2018) research, namely the number of Audit Committee meetings has a negative effect on REM. There are different research findings that make it interesting to re-examine between Susanto \& Pradipta, (2016); Devi \& Iskak (2018) with Thi, Khanh, and Khuong (2018) and Keong, (2020). The difference in the results of this study is interesting to mention again because of the development of the conditions of companies in Indonesia, based on several previous studies. Various research results indicate that previous researchers paid less attention to mediation issues which might clarify the direction of the research relationship. The existence of a mediating variable is expected to bridge the differences in previous research results. In this study, human capital is positioned as a mediating variable and is expected to explain the relationship between the expertise of the audit committee and the number of audit committee meetings with real earnings management. The contribution of this research to management practices and literary understanding of human capital related to real earnings management in companies in Indonesia. This study is a development of several previous studies which were only limited to the relationship between audit committee expertise and the number of audit committee meetings with real earnings management (Jianju \& Wang, 2018; Susanto \& Pradipta, 2016; Devi \& Iskak, 2018; Arturo et al., (2017); Pratiwi \& Meiranto, 2013) The addition of the human capital variable is also expected to provide support to the audit committee to minimize real earnings management practices.

The next section of this paper consists of background theory and hypothesis development. The next section research methods, resulte and discussion. The final section contains conclusions including limitations and suggestions for future research.

\section{Theoretical Background}

In this study, the relationship between audit committee expertise and number of audit committee meetings with real earnings management and human capital as a mediating variable is based on agency theory (Jensen \& Meckling, 1976) and resource based view (RBV) (Barney, 2000). The relationship between audit committee expertise and the number of audit committee meetings focuses more on agency theory, while human capital refers more to the RBV theory. Agency theory explains that principal and agent have different goals and preferences (Robert N. \& Vijay, 2007). Daily et al., (2003) stated that agency theory has two advantages, namely the agency theory conceptually reduces the company into two groups (managers and shareholders). Another advantage is that agency theory shows that managers can act according to their interests because managers understand the condition of the company as a whole. Agency theory underlies the relationship between agents such as company managers and principals, namely shareholders. Shareholders delegate the authority to manage the company to managers as agents, resulting in different interests between agents and managers and creating agency costs (Jensen \& Meckling, 1976). The condition of corporate governance is also considered a mechanism that requires managers to act in accordance with the wishes of the investor (principal) in generating profits and distributing dividends. Thus, the presence of the audit committee board is considered important in order to reduce agency conflicts that occur between managers and shareholders. The existence of differences in interests between agents and principals who are the focus of agency theory ignores other resources that are important to the company, such as human capital. The expertise of the audit committee and the number of audit meetings in corporate governance strategies view human capital as contributing to real earnings management. Real Earnings management refers to the management of income through normal activities which aims to influence income reporting through sales techniques, excess production, discretionary expenses and profits derived from sales of fixed assets (Graham, Harvey, \& Rajgopal (2005); Teguh, 2006; Zang, 2012; Huang \& Sun, 2017)). Several reasons underlying the shift in accrual earnings management to real earnings management are because accrual earnings manipulation is often the concern of auditors and regulators rather than decisions about pricing and production, so Ratmono (2010)explains that by taking real earnings management actions, auditors find it difficult to track cheating that happened. Roychowdhury (2006) explains that real earnings management shows good company performance in the short term, but has the potential to reduce the company's long-term performance, so that real earnings management is used as an alternative to signal investors regarding dividend distribution. If managers practice real earnings management, it will further exacerbate agency conflicts, because the manipulation by managers aims to mislead investors in understanding the company's financial condition. The position of the audit committee as an independent body is expected to reduce agency conflicts that occur between agents and principals. Educational background and knowledge of accounting and finance are important things for the audit committee to examine and analyze financial information that is used as a basis for decision making. The competence of the audit committee is indicated by an educational background 
and experience in finance, so that it is expected to be able to adopt accounting standards and have high achievements, and to be able to oversee the company's financial position (Pratiwi \& Meiranto, 2013).

The audit committee in carrying out its duties requires coordination with various parties, so that the audit committee meets regularly to evaluate management performance. The meeting is expected to reduce agency conflicts and can pressure managers into taking profit manipulation actions (Ali \& Kamardin, 2018). The Resource Based View theory has a basic philosophy that every resource has the ability to create products that have competitive advantages, which include ownership of features that are difficult to imitate, rare and cannot be replaced with others (Anifowose, Abdul, Annuar, 2018). Resource based view theory is based on the concept of competitive advantage by creating new products that are difficult to imitate (Barney, 2000). Product innovation cannot be separated from intangible assets that focus on human resources as the main driver in company operations. Resource based view emphasizes that human resources are very influential on competitive advantage (Lim, Chan, \& Dallimore, 2010). Human capital is currently an important investment for companies which includes developing employee skills in the form of experience or educational background. In this study, the human capital variable refers more to the Resource Based Value (RBV) theory which shows that human resources are an important asset owned by a company and can affect company performance (Mouritsenet al., 2001). Human capital includes salaries, compensation, bonuses, training costs and employee skills and competencies (Sarea \& Alansari, 2016).

\section{Hypothesis development}

The expertise of the audit committee, which is reflected in the level of education and experience in accounting, is expected to be able to analyze financial information for decision making. An audit committee with a good level of expertise is able to improve the quality of financial supervision and reporting, so that it can reduce manipulation practices through real earnings management.

\section{H1: Audit committee expertise has a negative effect on real earnings management.}

The Forum for Corporate Governance in Indonesia (FCGI) requires the audit committee to meet three to four times a year. The existence of internal control through routine and structured audit committee meetings can early detect problems that occur in the company. The more intense the number of audit meetings discussing existing problems, it is hoped that the quality of financial reports will also be more transparent, thereby reducing real earnings management actions.

\section{H2: The number of audit committee meetings has a negative effect on Real earnings management.}

The expertise of the audit committee shows the level of understanding in analyzing financial statements related to the quality of the preparation of financial statements. Increasing understanding of accounting provides proportional value in measuring intangible assets. An audit committee with a good understanding of accounting will appreciate the existence of human resources as an important asset for increasing company value. An audit committee who is increasingly skilled in understanding financial statements will improve human capital performance

\section{H3: The expertise of the audit committee has a positive effect on human capital.}

Audit committee meetings aim to discuss and evaluate financial reports, internal control and oversee corporate governance. The more frequent number of audit committee meetings is expected to increase coordination, effective monitoring and evaluation, so as to improve human capital performance.

\section{H4: The number of audit committee meetings has a positive effect on human capital performance.}

Marr et al., (2004) states that human capital is a group of assets in the form of knowledge possessed by employees and contributes significantly to increasing the competitive value of the company. Increased knowledge creates investment costs from intangible assets. The increased performance of human capital is marked by value creation in the form of product innovation, so as to increase competitive advantage. It is hoped that the improvement of human capital performance can reduce real earnings management practices.

\section{H5: Human capital performance has a negative effect on real earnings management.}

Expertise in accounting in analyzing financial statements is needed in companies because the main function of the audit committee is to oversee the financial reporting process of a company (Rustiarini, 2013). If the audit committee members have expertise in accounting and have good human capital performance, earnings management practices can be reduced.

\section{H6: Human Capital mediates the expertise of the audit committee on Real Earnings Management.}

The increasing frequency of audit committee meetings will increase supervision of the management in carrying out the company's operational activities. The number of intense meetings can also increase the performance of human capital, thereby reducing the practice of real earning management. 


\section{Research Methods}

This research is an empirical study which aims to examine the effect of audit committee expertise and number of audit committee meetings on real earnings management, with human capital as the mediating variable. The population of this research is manufacturing companies listed on the Indonesian stock exchange. The retrieval technique uses purposive sampling, with the criteria for manufacturing companies that publish financial reports consistently during 2015-2017 and companies that have complete data according to the research variables. Real Earnings management is a deviation from the company's normal activities carried out by managers with the aim of misleading shareholders about financial statement information (Roychowdhury, 2006). In this study, REM measurement uses three approaches, namely:

Abnormal operating activities cash flow (AbnCFO), is the difference from the value of actual operating activities cash flow which is scaled with the total assets of one year before the test minus the budgeted cash flow from operating activities.

$C F O_{t} / A_{t-1}=\alpha_{0}+\alpha_{1}\left(1 / A_{t-1}\right)+\beta_{1}\left(S_{t} / A_{t-1}\right)+\beta_{2}\left(\Delta S_{t} / A_{t-1}\right)+\epsilon_{t}$

Information:

$\mathrm{CFO}_{\mathrm{t}}=$ Cash flow from operating activities in year $t$.

$\mathrm{A}_{\mathrm{t}-1}=$ Total assets in year $t-1$.

$\mathrm{St}=$ Net sales in year $\mathrm{t}$.

$\Delta \mathrm{S}_{\mathrm{t}}=\mathrm{S}_{\mathrm{t}}-\mathrm{S}_{\mathrm{t}-1}$

Abnormal Discretionary Expenses (AbnDISEXP) obtained by subtracting the actual discretionary cost which was scaled from the total assets one year before the test period with budgeted discretionary costs.

$\operatorname{DISEXP} P_{t} / A_{t-1}=\alpha_{0}+\alpha_{1}\left(1 / A_{t-1}\right)+\beta\left(S_{t-1} / A_{t-1}\right)+\epsilon_{t}$

Note: DISEXP $\mathrm{t}_{\mathrm{t}}=$ discretionary costs at time $t$

Abnormal Production Costs (AbnPROD), namely the sum of the costs of goods sold in year t (COGSt) plus changes in inventories in that year $(\Delta \mathrm{INVt})$. The model for normal annual production costs is as follows:

$\operatorname{PROD}_{t} / A_{t-1}=\alpha_{0}+\alpha_{1}\left(1 / A_{t-1}\right)+\beta_{1}\left(S_{t} / A_{t-1}\right)+\beta_{2}\left(\Delta S_{t} / A_{t-1}\right)+\beta_{3}\left(\Delta S_{t-1} / A_{t-1}\right)+\epsilon_{t}$

Real Earnings Management measurement is obtained by adding up Abnormal CFO, Abnormal Discretionary and Abnormal production cost. From the explanation above, the following formula is obtained:

$R E M=A b n C F O+A b n D I S E X P+(A b n P R O D x(-1))$

Committee members' expertise includes certified public accountants, auditors, chief financial officers, chief accounting officers, accounting officers (Badolato, Donelson, \& Ege, 2014; Paredes \& Wheatley, 2017). Measurement of audit committee expertise by using audit committee ratios that have expertise on the number of audit committees. The number of committee meetings, namely regular meetings at least once in three months, and Audit Committee meetings can be held if attended by more than half of the members. Measuring the number of audit committee meetings by counting the number of meetings held in one year.

This research equation uses three steps, namely

$$
\begin{aligned}
& H C=\alpha+\beta_{1} \text { Expert }+\beta_{2} \text { Meeting }+e \\
& \text { REM }=\alpha+\beta_{1} \text { Expert }+\beta_{2} \text { Meeting }+e \\
& \text { REM }=\alpha+\beta_{1} \text { Expert }+\beta_{2} \text { Meeting }+\beta_{3} H C+e
\end{aligned}
$$

\section{Result and Discussion}

This research was conducted at manufacturing companies registered in Indonesia from 2015 to 2017 with a total sample of 90 companies. Data taken from the company's financial statements that are included in the sample criteria. This study uses path analysis using SPSS as an analysis tool with the following results:

\section{Table 1}

Statistical Results of Eq. (1)

\begin{tabular}{llll}
\hline & Unstandardized Coefficients (B) & t & Sig \\
\hline Expert Audit & .858 & .683 & .046 \\
Meeting Audit & -.205 & -.952 & .344 \\
\hline
\end{tabular}


From the results of data processing in Eq. (1), it can be explained with a significant level of 0.46 on the expertise of the audit committee showing that the expertise of the audit committee has a significant positive effect on human capital, while a significant level of 0.344 on the number of meetings shows that the number of meetings has no significant effect on human capital. From the data above, it can be explained that the hypothesis which states that audit committee expertise has a significant positive effect on human capital is accepted. Good committee expertise is reflected in the level of understanding and a good level of accounting education, so that it can compile quality financial reports. A good level of accounting understanding can improve capital performance. By increasing human capital, it can increase the competitive advantage of the company. The results of further research indicate that the number of audit committee meetings has no effect on human capital performance, so the hypothesis stating that the number of audit committee meetings has a significant positive effect on human capital is rejected. This happens because in the audit committee meeting the only concern is tangible assets, while intangible assets do not get enough attention.

\section{Table 2}

Regression Testing and Mediating Effect

\begin{tabular}{llll}
\hline & Unstandardized Coefficients (B) & $\mathrm{t}$ & Sig \\
\hline Expert Audit & -3342121670.723 & -.604 & .548 \\
Meeting Audit & -491834005.774 & -.516 & .607 \\
Human Cap & -895296140.876 & -1.898 & .061 \\
\hline
\end{tabular}

The effect of accounting expertise on REM shows insignificant negative effect, meaning that audit committee expertise does not significantly influence REM practice. This may occur because in the presentation of the financial statements the results of product sales for the research year have exceeded the target but are only reported according to the specified target. The excess sales are kept as a reserve if in the following year the sales target is not met. The number of audit committee members meeting has a negative and insignificant effect on REM. This shows that the more often the members of the audit committee hold meetings, the less influence they have on REM practice. The number of audit committee meetings held is limited to formality, it does not evaluate the financial statements in detail. REM practices carried out by managers cannot be detected by the audit committee (Ratmono, 2010). Human capital has a negative and insignificant effect on REM practice, thus high human capital performance does not directly affect the decline in real earnings management. The high performance of human capital is indicated by the existence of product innovation with the aim of being a competitive advantage for the company. However, the resulting product innovation does not have a direct effect on REM, this is because the new products produced have not been accepted by the market, so the level of sales is still low. Low sales levels cause managers to manipulate sales results to cover targets. The expertise of the audit committee and the number of audit meetings through human performance do not have a significant effect on REM. With the performance of human capital, which mediates the relationship between the expertise of the audit committee and the number of audit committee meetings, it turns out that it has no effect on REM actions. In this study, the existence of an audit committee does not reduce REM actions taken by managers. This is because committee members may not be independent in evaluating financial statements.

\section{Conclusion}

Real earnings management is an act of manipulating financial statements by managers with the aim of providing misleading financial information for shareholders. REM actions by managers can exacerbate agency conflicts that occur between managers and shareholders. The effectiveness of the audit committee with the expertise and number of audit committee meetings is seen as important in reducing agency conflicts.

This study shows that the expertise of the audit committee can improve human capital performance, but the number of audit committee meetings has no effect on human capital. Audit committee expertise, number of audit committee meetings and human capital performance have no effect on REM actions. The limitation of this study is the amount of company data, this is because there are still many companies that do not consistently publish financial reports every period. The research period is also still limited to only three years of research. In future studies, it is expected to add research variables including the effectiveness of the audit committee and to increase the number of years of research. The human capital variable can be developed into intellectual capital variables.

\section{References}

Ali, B., \& Kamardin, H. (2018). Real Earnings Management: A Review of Literature and Future Research. Asian Journal of Finance \& Accounting, 10(1), 440-456.

Anifowose, M., Rashid, H. M. A., Annuar, H. A., \& Ibrahim, H. (2018). Intellectual capital efficiency and corporate book value: Evidence from Nigerian economy. Journal of Intellectual Capital, 19(3), 644-668. 
Badolato, P. G., Donelson, D. C., \& Ege, M. (2014). Audit committee financial expertise and earnings management: The role of status. Journal of Accounting and Economics, 58(2-3), 208-230.

Barney. (2000). Firm resources and sustained competitive advantage. Economics Meets Sociology in Strategic Management, $17,203-227$.

Cohen, D., \& Zarowin, P. (2010). Accrual-based and real earnings management activities around seasoned equity offerings. Journal of Accounting and Economics, 50(1), 2-19.

Daily, Dalton, \& Canella. (2003). Corporate Governance: Decades Of Dialogue And Data. Academy of Management Review, $28(3)$.

Devi, C. M., \& Iskak, J. (2018). Pengaruh Corporate Governance, Profitabilitas , Leverage , Dan Kualitas Audit Terhadap Real Earnings Management. Jurnal Muara Ilmu Ekonomi Dan Bisnis, 2(1), 35-43.

Graham, J. R., Harvey, C. R., \& Rajgopal, S. (2005). The economic implications of corporate financial reporting. Journal of Accounting and Economics, 40(1-3), 3-73.

Gunny, K. A. (2010). The Relation Between Earnings Management Using Real Activities Manipulation and Future Performance : Evidence from Meeting Earnings Benchmarks. Contemporary Accounting Research, 27(3), 855-888.

Huang, X. S., \& Sun, L. (2017). Advances in Accounting Managerial ability and real earnings management. Advances in Accounting, 39(September), 91-104.

Jensen, M. C., \& Meckling, W. H. (1976). Theory of the firm: Managerial behavior, agency costs and ownership structure. Journal of Financial Economics, 3(4), 305-360.

Jianju, D., \& Wang, L. (2018). Ownership Concentration, Internal Control Quality And Real Earnings Management. IEEE Third International Conference on Data Science in Cyberspace (DSC), 438-444.

Keong, O. (2020). Determinants of Intentions to Engage in Sustainability Accounting \& Reporting (SAR) and Moderating Role of Internal Audit Function: The Perspective of Accountants. Arthatama, 4(1), 33-43.

Lim, Chan, \& Dallimore. (2010). Perceptions of Human Capital Measures: From Corporate Executives and Investors. Journal of Business and Psychology, 25(4).

Mouritsen, J., Larsen, \& Bukh. (2001). Valuing The Future: Intellectual Supplements at Skandia. Accounting, Auditing \& Accountability Journal, 14(4).

Paredes, A. A. P., \& Wheatley, C. (2017). The influence of culture on real earnings management. International Journal of Emerging Markets, 12(1), 38-57

Pratiwi, Y. D., \& Meiranto, W. (2013). Pengaruh Penerapan Corporate Governance Terhadap Earnings Management Melalui Manipulasi Akitivitas Riil. Diponegoro Journal Of Accounting, 2(1), 1-15.

Ratmono, D. (2010). Manajemen Laba Riil Dan Berbasis Akrual: Dapatkah Auditor Berkualitas Mendeteksinya? Simposium Nasional Akuntansi, XIII, 1-23.

Robert, N. A., \& Vijay, G. (2007). Management Control System, 12 Edition. New York,NY : McGraw-Hill Education.

Roychowdhury. (2006). Earnings management through real activities manipulations. Journal of Accounting and Economics, 42 , 335-370.

Rustiarini, N. W. (2013). Pengaruh Kompleksitas Tugas, Tekanan Waktu, dan Sifat Kepribadian pada Kinerja. Makara of Social Sciences and Humanities Series, 17(2), 126-138.

Sarea, A. M., \& Alansari, S. H. (2016). The relationship between intellectual capital and earnings quality: evidence from listed firms in Bahrain Bourse. International Journal of Learning and Intellectual Capital, 13(4), 302-315.

Susanto, Y. K., \& Pradipta, A. (2016). Corporate governance and real earnings management. Jurnal Internasional Bisnis, Ekonomi Dan Hukum, 9(1), 17-23.

Teguh, I. (2006). Earnings management through real activities manipulation. Journal of Accounting and Economics, 42, 335370.

Thi, H., Khanh, M., \& Khuong, N. V. (2018). Audit Quality, Firm Characteristics and Real Earnings Management: The Case of Listed Vietnamese Firms. International Journal of Economics and Financial Issues, 8(4), 243-249.

Zang, A. Y. (2012). Evidence on the trade-off between real activities manipulation and accrual-based earnings management. The accounting review, 87(2), 675-703.

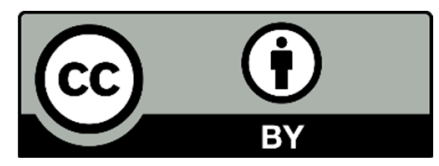

(C) 2021 by the authors; licensee Growing Science, Canada. This is an open access article distributed under the terms and conditions of the Creative Commons Attribution (CC-BY) license (http://creativecommons.org/licenses/by/4.0/). 